\title{
Structure of a New Antibiotic, Terrecyclol, from Aspergillus terreus Thom
}

\author{
Masahira Nakagawa, Heiichi SaKaI, Akira IsogaI* \\ and Akira Hirota \\ Department of Agricultural Chemistry, University of Osaka Prefecture, \\ Sakai, Osaka 591, Japan \\ *Department of Agricultural Chemistry, The University of Tokyo, \\ Bunkyo-ku, Tokyo 113, Japan \\ Received June 17, 1983
}

\begin{abstract}
The structure of a new sesquiterpene antibiotic, terrecyclol (I), from Aspergillus terreus Thom No. 14 was determined to be $\mathbf{I}$. The antimicrobial activity of $\mathbf{I}$ is as high as that of terrecyclic acid A (II), which is a main antimicrobial product of Asp. terreus No. 14.
\end{abstract}

In the previous papers ${ }^{1,2)}$ we have reported the isolation procedure, biological activities and chemical structure of a new sesquiterpene antibiotic terrecyclic acid A (II), which was produced from Aspergillus terreus Thom No. 14. II has the same novel carbon skeleton as does quadrone, ${ }^{3,4)}$ an antitumor substance produced by Aspergillus terreus. In continuation of the work we noticed antimicrobial activity against Bacillus subtilis in the neutral fraction of the culture filtrate of the same microorganism.

In this paper we wish to report the purification procedure, biological activity and structure of a new antibiotic, terrecyclol (I).

A. terreus No. 14 was cultivated at $30^{\circ} \mathrm{C}$ for six days on the medium described in EXPERIMENTAL. The culture broth (30 liters) was filtered and the culture filtrate was adsorbed to activated charcoal. The charcoal was extracted with acetone and next with ethyl acetate. The combined extracts were concentrated under reduced pressure and an ethyl acetate soluble neutral fraction was conventionally separated from the residue. The neutral fraction was applied to silica gel column chromatography (Wako gel C-200; solvent system, benzene-ethyl acetate). The antimicrobial activity against Bacillus subtilis was shown in the eluate with benzene containing

$20 \%$ ethyl acetate. This eluate was rechromatographed on a silica gel column with benzene containing $12 \%$ ethyl acetate to give a crude oil $(80 \mathrm{mg})$. The active substance (I) seemed to be a major component of the oil, but its impurities could not be removed. The crude oil was, however, reduced with sodium borohydride and the crystalline substance (III), mp $189 \sim 190^{\circ} \mathrm{C}$, was obtained in a high yield.

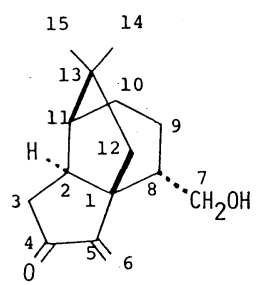

I

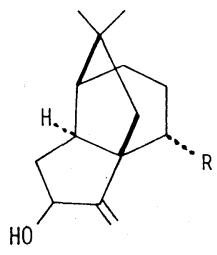

II I $\mathrm{R}=\mathrm{CH}_{2} \mathrm{OH}$

IV $\mathrm{R}=\mathrm{COOH}$

FIG. 1. Structures of I, II, III, IV and V.

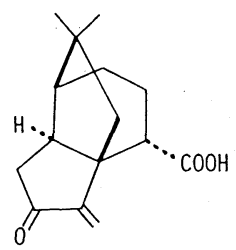

II

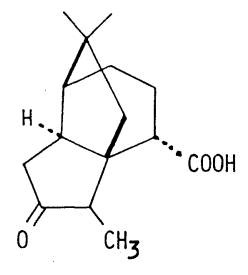

V 
By high resolution mass spectrometry, the molecular formula of III was determined to be $\mathrm{C}_{15} \mathrm{H}_{24} \mathrm{O}_{2}\left(\mathrm{M}^{+} m / z\right.$ 236.1796; 236.1776 calcd. for $\mathrm{C}_{15} \mathrm{H}_{24} \mathrm{O}_{2}$ ). III did not give a positive color reaction to 2,4-dinitrophenylhydrazine, while I did, and the IR spectrum of III showed no absorption band due to a carbonyl group.

In the ${ }^{1} \mathrm{H}$-NMR spectrum (in $d_{5}$-pyridine) of III there existed two broad singlets at $\delta 5.90$ and $\delta 6.70 \mathrm{ppm}$ attributable to hydroxyl protons. A broad triplet $(1 \mathrm{H}, J=8.1 \mathrm{~Hz})$ at $\delta 4.65 \mathrm{ppm}$ was due to the $-\mathrm{CH}_{2} \mathrm{CHOH}$ moiety, and a double doublet $(1 \mathrm{H}, J=9.5$, $2.8 \mathrm{~Hz})$ at $\delta 4.03 \mathrm{ppm}$ and a double doublet $(1 \mathrm{H}, J=9.5,9.5 \mathrm{~Hz})$ at $\delta 3.77 \mathrm{ppm}$ were assigned to the $-\mathrm{CH}-\mathrm{CH}_{2} \mathrm{OH}$ moiety. Other signals in the ${ }^{1} \mathrm{H}-\mathrm{NMR}$ spectrum of III were very similar to those in the ${ }^{1} \mathrm{H}-\mathrm{NMR}$ spectrum of terrecylic acid A (II). For example, two singlets at $\delta 5.04$ and $5.56 \mathrm{ppm}$ were attributable to exomethylene protons and this assignment was supported by the ${ }^{13} \mathrm{C}-\mathrm{NMR}$ spectrum of III $(\delta 104.00(\mathrm{t})$ and $163.46(\mathrm{~s}) \mathrm{ppm})$. Two doublet methyl protons at $\delta 1.06 \mathrm{ppm}$ and $1.09 \mathrm{ppm}$ also existed. Accordingly I was presumed to have a hydroxymethyl group instead of a carboxyl group at the C-7 position*1 of II.

II was reduced with sodium borohydride and a crystalline substance (IV), $\mathrm{mp} 187^{\circ} \mathrm{C}$, $\mathrm{C}_{15} \mathrm{H}_{22} \mathrm{O}_{3}\left(\mathrm{M}^{+} m / z 250\right)$, was obtained. The ${ }^{13} \mathrm{C}-\mathrm{NMR}$ spectral data of III and IV are shown in Table I. These two spectra were very similar each other except for a signal at $\delta 63.01 \mathrm{ppm}$ (t) in III and a signal at $\delta 177.61 \mathrm{ppm}$ (s) in IV. Concequently, the above-mentioned presumption was deemed reasonable.

Further, terrecyclic acid A (II) was reduced with lithium aluminum hydride and a crystalline substance was obtained. This substance, mp $189 \sim 190^{\circ} \mathrm{C}$, MS $\mathrm{M}^{+} m / z 236$, was identified to be III. III was then oxidized with manganese dioxide to yield an oily substance, which was identified as I by comparison with
TABle I. ${ }^{13}$ C-NMR Spectral Data of III (100 MHz, $d_{5}$-PYRIDINE) AND IV (25 MHz, $d_{5}$-PYRIDINE)

\begin{tabular}{cc}
\hline \multicolumn{2}{c}{$\delta$, ppm (multiplicity) } \\
\hline III & IV \\
\hline $21.44(\mathrm{t})$ & $23.37(\mathrm{t})$ \\
$26.92(\mathrm{q})$ & $27.32(\mathrm{q})$ \\
$28.64(\mathrm{t})$ & $29.75(\mathrm{t})$ \\
$35.02(\mathrm{q})$ & $35.10(\mathrm{q})$ \\
$38.80(\mathrm{~s})$ & $39.31(\mathrm{~s})$ \\
$39.15(\mathrm{t})$ & $39.31(\mathrm{t})$ \\
$47.92(\mathrm{~d})$ & $48.00(\mathrm{~d})$ \\
$48.07(\mathrm{~d})$ & $49.17(\mathrm{~d})$ \\
$49.32(\mathrm{~d})$ & $50.14(\mathrm{~d})$ \\
$55.91(\mathrm{t})$ & $55.40(\mathrm{t})$ \\
$56.60(\mathrm{~s})$ & $55.99(\mathrm{~s})$ \\
$63.01(\mathrm{t})$ & $76.75(\mathrm{~d})$ \\
$77.23(\mathrm{~d})$ & $104.48(\mathrm{t})$ \\
$104.00(\mathrm{t})$ & $163.57(\mathrm{~s})$ \\
$163.46(\mathrm{~s})$ & $177.61(\mathrm{~s})$ \\
\hline
\end{tabular}

their $R f$ values on some thin layer chromatogram plates and with their IR spectra (Fig. 2). The structure of $I$ was determined as shown in Fig. 1 and $\mathbf{I}$ was named terrecyclol.

The configuration of terrecyclol (I) is the same as that of terrecyclic acid $\mathrm{A}$ (II), because four assymetric centers $\left(\mathrm{C}_{1}, \mathrm{C}_{2}, \mathrm{C}_{8}\right.$ and $\left.\mathrm{C}_{11}\right)$ seem to be unchanged in the reactions from II to I. II was easily pyrolyzed at $190^{\circ} \mathrm{C}$ in an oil bath to afford quadrone. ${ }^{2)}$ Accordingly, the stereochemistry of the four assymetric centers of I, II and quadrone should be the same.

The relative stereochemistry of quadrone was determined by a direct single X-ray analysis. $^{4)}$ We tried to ascertain the relative stereochemistry of these novel sesquiterpenes by a Nuclear Overhauser Enhancement experiment. This experiment was conducted with the diazomethane adduct of the methyl ester of II, the $400 \mathrm{MHz}{ }^{1} \mathrm{H}-\mathrm{NMR}$ spectrum of which was completely analyzed. ${ }^{2)}$ The results are shown in Scheme 1, and the relative stereochemistry of quadrone, which was proposed by Ranieri and Calton, ${ }^{4)}$ was supported by the NOE experiment. quadrone. 


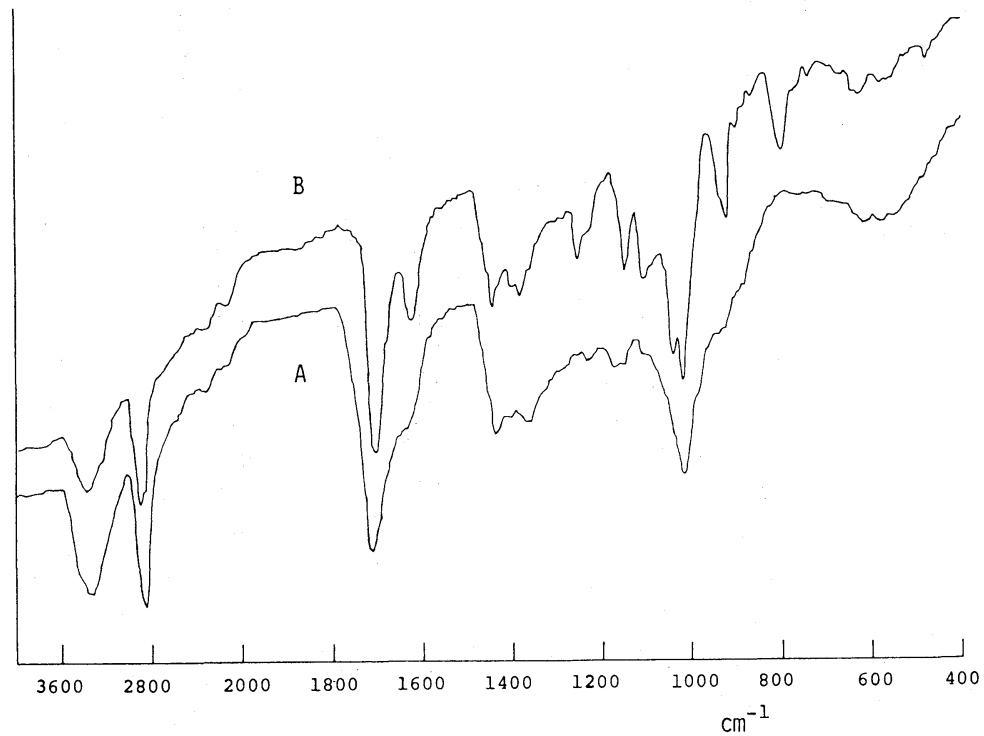

FIG. 2. IR Spectra of Crude I (A) and I Derived from II (B) (Film).

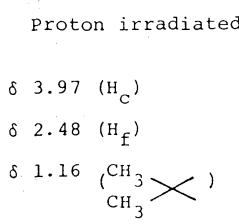

Nuclear Overhauser

Enhancement observed on

$\mathrm{H}^{\prime}, \mathrm{H}_{\mathrm{g}}, \mathrm{H}_{\mathrm{h}}$

$\mathrm{H}_{\mathrm{m}}$

$H_{e}, H_{h}, H_{j}, H_{k}, H_{m}, H_{n}$

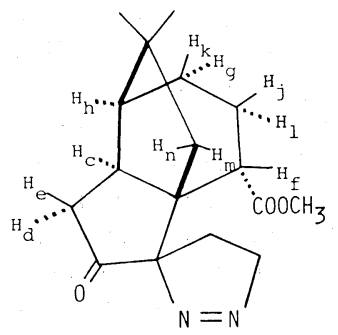

SCHEME 1. NOE Experiment of the Diazomethane Adduct of the Methyl Ester of II.

The antimicrobial spectrum of terrecyclol*2 is shown in Table II. I showed slightly high activities against gram-positive bacteria compared with II, and I also showed rather weak activities against $P$. chrysogenum and $F$. oxysporum.

Since III and IV have no antimicrobial activity, the carbonyl group at the C-4 position is necessary for this activity. II was hydrogenated over palladium-charcoal to give a crystalline compound (V), $\mathrm{mp} 128 \sim 129^{\circ} \mathrm{C}$, MS $\mathbf{M}^{+} m / z$ 250. From spectroscopic data, the structure of $\mathbf{V}$ was determined as shown in Fig. 1. $\mathbf{V}$ also had no antimicrobial activity. In conclusion an $\alpha$-methylene carbonyl moiety is essential for antimicrobial activity and, as Kupchan et al. have stated, ${ }^{5)}$ an electrophilic $\alpha$-methylene ketone might be the carrier of biological activity in the studies of antitumor substances from higher plants.

\section{EXPERIMENTAL}

. Melting points were determined on a microscope hot plate from Yanagimoto Co. and are uncorrected. The optical rotation was measured with a JASCO DIP-SL polarimeter, and the IR spectra were recorded on a JASCO IRA-2 infrared spectrometer. The $400 \mathrm{MHz}{ }^{1} \mathrm{H}$ $\mathrm{NMR}$ and $25 \mathrm{MHz}{ }^{13} \mathrm{C}-\mathrm{NMR}$ spectra were measured with a JNM-FX-400 and a JNM-FX-100 spectrometer, respectively. Mass spectra and high resolution mass spectra were obtained with a Hitachi RMU-6M and a JEOL JMS D300 mass spectrometer, respectively.

*2 Since the impurities could not be removed, terrecyclol artificially derived from terrecyclic acid A was used in the bioassay. 
Table II. Antimicrobial Spectra of I, II, III, IV and V

\begin{tabular}{|c|c|c|c|c|c|}
\hline & \multicolumn{5}{|c|}{$\mathrm{MIC}(\mathrm{mcg} / \mathrm{ml})$} \\
\hline & $\mathbf{I}$ & II & III & IV & $\mathbf{V}$ \\
\hline Staphylococcus aureus IFO 3060 & 25 & 25 & $>500$ & $>500$ & $>500$ \\
\hline Bacillus subtilis IFO 12210 & 12 & 50 & $>500$ & $>500$ & $>500$ \\
\hline Micrococcus roseus IFO 3764 & 12 & 25 & $>500$ & 500 & 500 \\
\hline Escherichia coli $\mathrm{K}-12$ IFO 3301 & $>200$ & $>200$ & $>500$ & $>500$ & $>500$ \\
\hline Pseudomonas aeruginosa IFO 3923 & $>200$ & 200 & $>500$ & $>500$ & $>500$ \\
\hline Serratia marcescens IFO 12648 & $>200$ & $>200$ & $>500$ & $>500$ & $>500$ \\
\hline Aspergillus niger IFO 4416 & $>200$ & $>200$ & $>500$ & $>500$ & $>500$ \\
\hline Penicillium chrysogenum IFO 4897 & 25 & 200 & $>500$ & $>500$ & $>500$ \\
\hline Fusarium oxysporum IFO 5880 & 25 & 200 & $>500$ & $>500$ & $>500$ \\
\hline Candida albicans & $>200$ & 150 & $>500$ & $>500$ & $>500$ \\
\hline
\end{tabular}

Cultivation. The medium composition was glucose $30 \mathrm{~g}$, soybean meal $2.5 \mathrm{~g}$, yeast extract $0.5 \mathrm{~g}, \mathrm{KH}_{2} \mathrm{PO}_{4} 1 \mathrm{~g}$, $\mathrm{MgSO}_{4} \cdot 7 \mathrm{H}_{2} \mathrm{O} \quad 1 \mathrm{~g}, \quad \mathrm{NaCl} \quad 0.5 \mathrm{~g}, \quad \mathrm{CaCl}_{2} \cdot 2 \mathrm{H}_{2} \mathrm{O} \quad 0.5 \mathrm{~g}$, $\mathrm{FeCl}_{3} \cdot 2 \mathrm{H}_{2} \mathrm{O} 2.0 \mathrm{mg}$, and $\mathrm{ZnSO}_{4} \cdot 7 \mathrm{H}_{2} \mathrm{O} 2.0 \mathrm{mg}$ in $1,000 \mathrm{ml}$ of tap water and it was adjusted to $\mathrm{pH} 5.5$ before sterilization. Fermentation was carried out $30^{\circ} \mathrm{C}$ for six days on a rotary shaker and $\mathrm{CaCO}_{3}$ (one gram per" one liter) was added at the 2 nd day.

Purification of terrecyclol (I). The culture filtrate (30 liters, $\mathrm{pH}$ ca. 4.3) was adsorbed on activated charcoal $(390 \mathrm{~g})$ and eluted first with acetone and then with ethyl acetate. The combined extracts were concentrated under reduced pressure and the residue was dissolved in water, adjusted to $\mathrm{pH} 3.0$ with dil. hydrochloric acid and extracted with ethyl acetate. The organic layer was washed with sodium bicarbonate solution and the neutral fraction $(7 \mathrm{~g})$ was obtained after drying over anhydrous sodium sulfate and removing the solvent. The neutral fraction was applied to a silica gel column (Wako gel C-200, $100 \mathrm{~g}$ ) and eluted with benzene-ethyl acetate $(80: 20)$. After concentrating the active fractions, the concentrate was applied to a silica gel column (Wako gel C-200, 27 g) and eluted with bezene-ethyl acetate $(88: 12)$. Concentration of the active fractions gave a crude oil $(80 \mathrm{mg})$. Terrecyclol (I) is a major component of the crude oil, and $R f$ values of $I$ on thin layer chromatogram plates (Merck $\mathrm{GF}_{254}, 0.25 \mathrm{~mm}$ thickness) are 0.48 (benzene-MeOH, $4: 1$ ) and 0.55 (ethyl acetatl). I was positive to 2,4-dinitrophenylhydrazine and was also detected on a Merck $\mathrm{GF}_{254}$ silica gel plate under a UV lamp (2536 $\AA$ ). The IR spectrum of crude I is shown in Fig. 2.

Reduction of I with sodium borohydride. Crude I (20 mg) was treated with sodium borohydride $(20 \mathrm{mg})$ in 2-propanol $(5 \mathrm{ml})$ at room temperature for $40 \mathrm{~min}$ and to the reaction mixture was added water $(5 \mathrm{ml})$. After standing overnight at room temperature, the reaction mixture was concentrated in vacuo and extracted with ethyl acetate.
The extract was applied to a silica gel column (Wako gel C200). Crude III was eluted with benzene-ethyl acetate (70:30) and recrystallized from $n$-hexane-ethyl acetate to afford needles $(14 \mathrm{mg}) . \mathrm{mp} 189 \sim 190^{\circ} \mathrm{C}$. $[\alpha]_{\mathrm{D}}^{24}-146.8^{\circ}(c=$ $0.07, \mathrm{EtOH})$. MS $m / z$ (abundance): $236\left(\mathrm{M}^{+}, 1.6\right), 221$ (0.9), 218 (0.5), 205 (10.9), 179 (100), 161 (8.0), 149 (14.5). IR $v_{\max }^{\mathrm{KBr}} \mathrm{cm}^{-1}: 3250$ (broad), 2950, 2900, 1470, 1090, 1060, 1035, 890. ${ }^{1} \mathrm{H}-\mathrm{NMR}\left(400 \mathrm{MHz}, d_{5}\right.$-Pyr., ppm): $\delta 1.06(3 \mathrm{H}$, s), $1.09(3 \mathrm{H}, \mathrm{s}), 1.56(1 \mathrm{H}, \mathrm{m}), 1.64(1 \mathrm{H}, \mathrm{m}), 1.71(1 \mathrm{H}, \mathrm{t})$, $1.77(1 \mathrm{H}, \mathrm{d}), 1.88(1 \mathrm{H}, \mathrm{d}), 1.90(1 \mathrm{H}, \mathrm{d}), 1.95(1 \mathrm{H}, \mathrm{dd})$, $2.00 \sim 2.25(4 \mathrm{H}, \mathrm{m}), 3.77(1 \mathrm{H}, \mathrm{dd}), 4.03(1 \mathrm{H}, \mathrm{dd}), 4.65(1 \mathrm{H}$, br. t), $5.04(1 \mathrm{H}, \mathrm{s}), 5.56(1 \mathrm{H}, \mathrm{s}), 5.90(1 \mathrm{H}$, br. s), $6.70(1 \mathrm{H}$, br. s). ${ }^{13} \mathrm{C}$-NMR (100 MHz, $d_{5}$-Pyr., ppm): Table I.

Reduction of II with sodium borohydride. Terrecyclic acid A (II) $(50 \mathrm{mg})$ was treated with sodium borohydride $(20 \mathrm{mg})$ in 2-propanol $(5 \mathrm{ml})$ at room temperature for $30 \mathrm{~min}$ and water $(5 \mathrm{ml})$ was added. After standing for $30 \mathrm{~min}$, the reaction mixture was concentrated in vacuo and extracted with ethyl acetate at $\mathrm{pH} 3$. Crude IV was obtained from the extract and was recrystallized from ethyl acetate to afford needles $(40 \mathrm{mg}) . \mathrm{mp} 187^{\circ} \mathrm{C}$. MS $\mathrm{m} / \mathrm{z}$ (abundance): $250\left(\mathrm{M}^{+}, 1.2\right), 235(1.2), 232(0.4), 193(100)$, 149 (9.2), 147 (9.7). IR $v_{\max }^{\mathrm{KBr}} \mathrm{cm}^{-1}: 3420,3360,2950$ (broad), 1730, 1690, 1450, 1320, 1240, 1210, 1180, 1135, 1080, 1060, 1050, 980, 880. ${ }^{1} \mathrm{H}-\mathrm{NMR}\left(400 \mathrm{MHz}, d_{5}\right.$-Pyr., ppm): $\delta 1.05(3 \mathrm{H}, \mathrm{s}), 1.13(3 \mathrm{H}, \mathrm{s}), 1.71(1 \mathrm{H}, \mathrm{m}), 1.73(1 \mathrm{H}$, d), $1.79(1 \mathrm{H}$, br. t), $1.82(1 \mathrm{H}, \mathrm{m}), 1.96(1 \mathrm{H}, \mathrm{d}), 2.07(1 \mathrm{H}, \mathrm{d})$, $2.08(1 \mathrm{H}, \mathrm{m}), 2.18(1 \mathrm{H}, \mathrm{ddd}), 2.33(1 \mathrm{H}, \mathrm{ddd}), 3.05(1 \mathrm{H}$, dd), $3.17(1 \mathrm{H}, \mathrm{d}), 5.18(1 \mathrm{H}, \mathrm{m}), 5.22(1 \mathrm{H}$, br. s), $5.64(1 \mathrm{H}$, br. s). ${ }^{13} \mathrm{C}-\mathrm{NMR}$ ( $25 \mathrm{MHz}, d_{5}$-Pyr., ppm): Table I.

Reduction of II with lithium aluminum hydride. Terrecyclic acid A (II) (1 g) was treated with lithium aluminum hydride $(1 \mathrm{~g})$ in ethyl ether $(30 \mathrm{ml})$. The mixture was stirred at room temperature for $20 \mathrm{hr}$ and to the reaction mixture was added water. The reaction mixture was filtered and the filtrate was evaporated in vacuo. The residue was extracted with ethyl acetate, the extract was 
applied to a silica gel column (Wako gel C-200, $15 \mathrm{~g}$ ) and the column was eluted with benzene-ethyl acetate $(85: 15)$. Crude crystals obtained were recrystallized to afford colorless needles $(137 \mathrm{mg}) . \mathrm{mp} 189.0 \sim 190.5^{\circ} \mathrm{C} .[\alpha]_{\mathrm{D}}^{24}-134.6^{\circ}$ $(c=0.16, \mathrm{EtOH})$. The IR and mass spectra were identical with those of III.

Oxidation of III with manganese dioxide. III (91 mg) was treated with activated manganese dioxide $(300 \mathrm{mg})$ in acetone $(25 \mathrm{ml})$ and the mixture was stirred at room temperature for $7.5 \mathrm{hr}$. The reaction mixture was filtered and the filtrate was evaporated in vacuo. The residue was extracted with ethyl acetate, the extract was applied to a silica gel column (Wako gel C-200, 15 g) and the column was eluted with benzene-ethyl acetate $(85: 15)$. I was obtained as a colorless oil $(33 \mathrm{mg}) .[\alpha]_{\mathrm{D}}^{24}+8.5^{\circ} \quad(c=0.3$, EtOH). MS $m / z$ (abundance): $234\left(\mathrm{M}^{+}, 100\right), 219(28)$, $178(28), 177$ (50), 163 (56), 147 (63), 119 (38). $R f$ values on tlc plates were identical with those of natural I. The IR spectrum of this oil is shown in Fig. 2.

Catalytic reduction of II. II (100 mg) was dissolved in methanol $(10 \mathrm{ml})$ and hydrogenated over $10 \%$ palladiumcharcoal catalyst $(20 \mathrm{mg})$ under atmospheric pressure for $10 \mathrm{~min}$. The reaction mixture was filtered, and the catalyst was washed with methanol. The combined filtrates were evaporated in vacuo to afford crude $\mathbf{V}(90 \mathrm{mg})$, which was recrystallized from $n$-hexane-ethyl acetate to give pure $\mathbf{V}$ as colorless needles. mp $128 \sim 129^{\circ} \mathrm{C}$. MS $\mathrm{m} / \mathrm{z}$ (abundance): $250\left(\mathrm{M}^{+}, 8.1\right), 235$ (9.5), 232 (2.0), 193 (100), 163 (10.7), 121 (10.1). IR $v_{\max }^{\mathrm{KBr}} \mathrm{cm}^{-1}: 3150$ (broad), 2940, 1710 (broad), 1450, 1380, 1290, 1240, 1190, 1160, 1060, 1040, 855. ${ }^{1} \mathrm{H}-\mathrm{NMR}\left(400 \mathrm{MHz}, \mathrm{CDCl}_{3}, \mathrm{ppm}\right): \delta 1.03(3 \mathrm{H}, \mathrm{d}$ ), $1.13(3 \mathrm{H}, \mathrm{s}), 1.16(3 \mathrm{H}, \mathrm{s}), 1.41(1 \mathrm{H}, \mathrm{d}), 1.45(1 \mathrm{H}, \mathrm{d}), 1.81$ $(1 \mathrm{H}, \mathrm{m}), 1.85 \sim 2.00(4 \mathrm{H}, \mathrm{m}), 2.39(1 \mathrm{H}, \mathrm{dd}), 2.48(1 \mathrm{H}, \mathrm{q})$,
$2.54(1 \mathrm{H}, \mathrm{dd}), 2.79(1 \mathrm{H}, \mathrm{d}), 2.79(1 \mathrm{H}, \mathrm{dd})$. In addition to these signals, there existed a broad singlet $(1 \mathrm{H})$ at $\delta 10.1$ ppm in the $100 \mathrm{MHz}{ }^{1} \mathrm{H}-\mathrm{NMR}$ spectrum $\left(\mathrm{CDCl}_{3}\right) \cdot{ }^{13} \mathrm{C}$ NMR (25 MHz, $\left.\mathrm{CDCl}_{3}, \mathrm{ppm}\right): \delta 8.57(\mathrm{q}), 22.17(\mathrm{t}), 27.17$ (q), 34.19 (q), 39.55 (s), 40.45 (t), 45.02 (d), $47.68(\mathrm{t}), 48.03$ (d), 49.32 (d), 51.60 (d), 54.93 (s), 181.24 (s), 218.83 (s).

Antimicrobial assay. The minimal inhibitory concentration of I, II, III, IV and V was determined by the agar dilution method using bouillon agar for bacteria and Czapek's agar for fungi and yeast. Observation was made after an $18 \mathrm{hr}$ incubation for bacteria and a $36 \mathrm{hr}$ incubation for fungi and yeast at $30^{\circ} \mathrm{C}$.

Acknowledgments. We wish to express our thanks to Mr. K. Furihata and Dr. H. Seto of the Institute of Applied Microbiology, The University of Tokyo, for measurements of $400 \mathrm{MHz}{ }^{1} \mathrm{H}-\mathrm{NMR}$ spectra and the $100 \mathrm{MHz}{ }^{13} \mathrm{C}$-NMR spectrum. We are also grateful to Dr. H. Hirota of the Department of Chemistry, The University of Tokyo, for his measurement of high resolution mass spectra and helpful discussions.

\section{REFERENCES}

1) M. Nakagawa, A. Hirota, H. Sakai and A. Isogai, $J$. Antibiot., 35, 778 (1982).

2) A. Hirota, M. Nakagawa, H. Sakai and A. Isogai, $J$. Antibiot., 35, 783 (1982).

3) G. J. Calton, R. L. Ranieri and M. A. Espenshade, J. Antibiot., 31, 38 (1978).

4) R. L. Ranieri and G. J. Calton, Tetrahedron Lett., 499 (1978).

5) S. M. Kupchan, M. A. Eakin and A. M. Thomas, $J$. Med. Chem., 14, 1147 (1971). 